\title{
Project Based Learning by Utilizing Used Material to Improve Students' Creativity in Primary School
}

\author{
Suryanti, Gita R. Paramitha \\ Universitas Negeri Surabaya \\ Surabaya, Indonesia \\ suryanti@unesa.ac.id
}

\begin{abstract}
Creativity is important in the 21st century and the ASEAN economic community era. Used materials are infrequently used, especially as a learning media. This research aims to investigate the effect of used materials usage on Project Based Learning towards students' creativity. This research is experimental research with a quasi-experimental design, i.e. nonequivalent control group design. Samples were taken randomly $(n=70)$. Data was taken from tests and observations. Based on the results of data analysis by different test there are differences in students' creativity in both groups. The difference of students' creativity shows that the improvement of students' creativity in the experimental class which applied the Project Based Learning is higher than in the control class. This shows that Project Based Learning has an effect on students' creativity in used materials usage. Learning activities with Project Based Learning is recommended by utilizing used material to improve students' creativity.
\end{abstract}

Keywords-project-based learning, students' creativity

\section{INTRODUCTION}

Creativity has an important role in the development of the 21 st century. Creativity is one of the most important skills in scoring success in the 21 st century and as an individual competence in adjusting to the changes occurring in the $21 \mathrm{st}$ century [1]. The changes are technology and scientific. The ASEAN Economic era is a free trade system among ASEAN member countries that provides a wider space on the economy. Competition in the ASEAN is very strict, either human resources or the product. Therefore, innovations that provide higher competitiveness are needed. To increase the competitiveness, creativity has an important role in this regard. Individual creativity can increase the innovative products [2]. Creativity is needed in problem solving [3]. One of the problems that occur today is about the accumulation of waste. Indonesia occupies the second position of the largest waste contributor after China. Each year Indonesia is able to contribute up to 187.2 million tons of waste. While China reached 262.9 million tons. Neighboring countries such as the Philippines are in the third position with 83.4 tons of waste production to the sea. One way to overcome the problem is by recycling. Under such conditions, essential creativity is possessed by human resources to be able to provide diverse ideas and perspectives in the face of existing challenges. Therefore, it is necessary to improve the quality of human resources primarily in the students as the next generation.
Improving the quality of human resources can be balanced with the quality of education. This is because creativity is essentially the key in individual progress where schools have a role in developing students' creativity through classroom activities [4].

[3] found that Project Based Learning with worksheets had affected the creative thinking of students. This is because the project-based learning model trains students to design, analyze and apply their ideas [3]. The worksheet used in the projectbased learning model includes planning to complete the product as a result of the project. [5] suggests that the use of the Project Based Learning model contributes more to the success of students compared to the use of direct learning models. This is due to the students' activity in learning with project-based learning model through the discovery activities undertaken by students. However, a teacher and students need involvement to share experiences in the learning process and find information from the internet. Another researched by [6] found a positive influence on students' motivation and learning outcomes in the project-based learning. In addition, [7] found that the application of project-based learning shows a positive influence on students' attitudes and collaborative work that can contribute to the attendance of students in learning. Other research by [8] found that the project-based learning affects the level of students' creativity. In addition [9] found an increase in creative thinking skills of students in making projects dealing with waste in the school environment.

This study aims to investigate the effect of utilization of used materials by the Project Based Learning model on students' creativity. The results of this study are expected to develop students' creativity in utilizing used materials with project-based learning model. The effectiveness of learning depends on the interaction of teachers, students and syllabus used [4]. The syllabus contained learning model. Selection of learning models has an influence on the quality of learning that has implications on the development of students' creativity. Creativity is a thinking skill that can be learned by doing so that students get direct experience of the learning. One of the models that became the learning innovation that supports to develop the capabilities needed by individuals in the 21 st century is the model of Project Based Learning [10]. Through the students' activity in the model of Project Based Learning, they will be able to develop their creativity. The learning process that emphasizes students' activities in 
problem solving with scientific skills such as researching, analyzing, creating, and displaying products is obtained through experience. This will give students the opportunity to be creative in producing a real product. Previous researches centered on the application of the project-based learning in the discussion of the abstract, the effect of the model projectbased learning on cognitive, attitude and motivation of students, the impact on students' creativity in using a tool, as well as the use of used materials to add value to art. This study, however, focuses on the use of used materials by applying the project-based learning model which aims to develop students' creativity in order to reduce the accumulation of waste that can be used as media for student learning. Creativity indicators used are fluency, flexibility, and originality and focuses on science learning with ecosystem topics and basic competencies to present observations on the components and types of ecosystems.

\section{METHOD}

This research was a quantitative research. The method used was quasi-experiment with non-equivalent control group design. This research had compared learning by applying project-based learning model and conventional learning that made different influence on students' creativity.

The population of this research was all of the fifth-grade students of SDN Manukan Kulon Surabaya. There are 184 students, 77 boys and 107 girls. A sample of this research was two classes chosen randomly with total 70 students. VC was chosen as the control class and VE was as the experimental class with 35 students in each class, i.e. 15 boys and 20 girls in class VC and 18 boys and 17 girls in class VE.

In this research, the students' creativity data was obtained through test and observation methods. The test is writing test which is used twice, that is before given treatment (pretest) and after given treatment (posttest). Observations were used to support the research data.

The pretest done before the learning is given in both classes in order to know the creativity of the students before the learning. On the next day, 7 hours of lessons are taught with 35 minutes time allocation per class in experiment and control class. In the experimental class, the model of projectbased learning was used, while in the control class, study group investigation was used. After the learning is done, another test (pretest) to determine the creativity of students was held. The indicators of students' creativity used in this research are fluency, flexibility, and originality.

Instruments in this study are test instruments and non-test instruments. The test instrument was obtained from the written test, while the non-test instrument was in the form of observation sheet obtained from the observation of students' tasks. The written test used is a description of 6 items. The project observation sheet contains aspects of project planning, implementing and reporting.

To determine the effect of project-based learning model on students' creativity, pretest and post-test result from both classes were analyzed with n-gain and t-test.

\section{RESULT AND DISCUSSION}

Data on students' creativity with indicators of fluency, flexibility and originality are presented in Table I.

TABLE I. STUDENTS' CREATIVITY

\begin{tabular}{|c|c|c|c|c|c|c|}
\hline \multirow{2}{*}{\begin{tabular}{c} 
Indicator $\begin{array}{c}\text { Ef } \\
\text { of } \\
\text { Creativity }\end{array}$ \\
\cline { 2 - 7 }
\end{tabular}} & \multicolumn{3}{|c|}{ pxperiment class } & \multicolumn{3}{c|}{ Control class } \\
\hline Fluency & 8.31 & 16.23 & 0.5663 & 8.31 & 12.09 & 0.3997 \\
\hline Flexibility & 8.29 & 36.69 & 0.6800 & 7.20 & 26.06 & 0.5074 \\
\hline Originality & 16.14 & 32.83 & 0.6920 & 16.57 & 31.57 & 0.4980 \\
\hline $\begin{array}{c}\text { Total } \\
\text { Score }\end{array}$ & 22.91 & 60.80 & 0.8000 & 22.57 & 49.46 & 0.6000 \\
\hline
\end{tabular}

Table 1. shows the differences that can be seen in the $\mathrm{N}$ Gain test results obtained by each class. Of the overall creativity, the N-Gain in the experimental class is 0.8 and the control class is 0.6 . This shows that students' creativity development in experiment class is more than control class. The significance of the n-gain difference between the two classes is presented in Table II.

TABLE II. STUDENTS' CREATIVITY

\begin{tabular}{|c|c|c|c|c|c|c|}
\hline Class & $\mathrm{N}$ & $\mathrm{Df}$ & $\mathrm{X}$ & $\mathrm{SD}$ & $\mathrm{t}_{\text {hitung }}$ & $\mathrm{t}_{\text {tabel }}$ \\
\hline Experiment & 35 & 68 & 0,8 & 0,137 & 2,784 & 1,9935 \\
\hline Control & 35 & & 0,6 & 0,213 & & \\
\hline
\end{tabular}

Based on Table II, after normality and homogeneity test, the t-test was obtained with the value 2.784 . Since t-test $>$ ttable (2.784> 1.9935), this means there is a significant difference between the gain of the experimental and control class. Observation of students' creativity is shown in Table 3.

TABLE III. STUDENTS' CREATIVITY

\begin{tabular}{|c|c|c|}
\hline \multirow{2}{*}{ Indicator } & \multicolumn{2}{|c|}{ Class } \\
\cline { 2 - 3 } & Control & Experiment \\
\hline Fluency & 8,34 & 9,06 \\
\hline Flexibility & 8,57 & 12,26 \\
\hline Originality & 1,57 & 3,34 \\
\hline
\end{tabular}

From Table III, it can be seen that the product in the experimental class gets a higher grade than the control class. Based on the students' indicator on the experimental class, the students have more ideas and points of view than the control class. The fluency indicator shows that students in the experimental class use a variety of used goods. Similarly, the flexibility indicator showing that the students use the used materials with a variety of forms and how to make it. In addition to the indicators of originality, students are also better to combine used materials to produce a new form. Unlike the control class that only use a maximum of 2 used materials. In addition, the way and the combination are poor. Similarly, in picture 1 and 2 showing the products of students in the experimental and control classes, there is difference in terms of material selection, variations and combinations contained in the indicator of creativity. 
The difference of students' creativity shows that the improvement of students' creativity in the experimental class that applied the model of Project Based Learning is higher than the improvement of students' creativity in the control class. This shows that the model of Project Based Learning has an influence on the creativity of students in utilizing used materials.

Creativity is a thought or idea that can create a different product from an existing one although it is not always new [11]. They explained that a person has creativity if he has the ability to generate ideas in large quantities, poses a variety of problem-solving, sparks original and combined ideas, outlines ideas in detail, and examines problems with different points of view.

[12] mentioned the advantages of Based Project Learning model which can improve students' thinking skills in analyzing a problem. In addition, the model of Project Based Learning is in line with modern learning where students have individual skills and cooperation, learning is inseparable from real life, as well as the development of students' activities, creativity, and experiences.

Based on the theory of creativity and excess model of Project Based Learning that has been described above, it shows that Project Based Learning model influence the creativity of students both in the learning process and in producing a product with the development of activity, creativity, and experience, so as to develop ideas as well as new ideas. This is supported by the theory of meaningful learning and the theory of learning constructivism. Both learning theories give students experience in learning. In the theory of meaningful learning by David Ausubel, that in helping students inculcate new knowledge the initial concepts is required, i.e. that is the one that students already have. So when using the learning model based on the problem, students are able to solve the problem by applying the initial concept that they already have [13].

In addition, constructivism learning theory emphasizes the importance of students in associating experiences, phenomena, and new facts into the system of understanding that has been owned. [13] states that in this theory students have to find, change complex information, check new information with old rules and improve if not suit independently. Thus, students will understand and apply knowledge through problemsolving and the discovery of new ideas for themselves. The discovery of new ideas will develop students' creativity.

\section{CONCLUSION}

Based on data analysis and discussion of research results, there are differences of students' creativity development in control class and experimental class which shows that students' creativity development in experiment class is higher than control class. So it can be concluded that the utilization of used materials on project-based learning model can develop students' creativity. In order for students' creativity to develop maximally, there needs to be a preparation of sources and learning media that are more diverse in the utilization of used goods. It is also necessary to adjust the time allocation to give students the opportunity to design the project better.

\section{REFERENCES}

[1] D. Henriksen, P. Mishra, and P. Fisser, "Infusing creativity and technology in 21 st century education: a systemic view for change," Journal of Educational Technology \& Society, vol. 19, p. 27, 2016.

[2] H. G. Çekmecelioğlu and A. Günsel, "The effects of individual creativity and organizational climate on firm Innovativeness," Procedia-Social and Behavioral Sciences, vol. 99, pp. 257-264, 2013.

[3] S. Mihardi, M. B. Harahap, and R. A. Sani, "The effect of project based learning model with kwl worksheet on student creative thinking process in physics problems," Journal of Education and Practice, vol. 4, pp. 188-200, 2013.

[4] H. M. Hatamleh, "Uprising of Creation in Education," Journal of Education and Practice, vol. 6, pp. 114-128, 2015.

[5] N. R. Ergül and E. K. Kargın, "The effect of project based learning on students' science success," Procedia-Social and Behavioral Sciences, vol. 136, pp. 537-541, 2014.

[6] E. Zouganeli, V. Tyssø, B. Feng, K. Arnesen, and N. Kapetanovic, "Project-based learning in programming classes-the effect of open project scope on student motivation and learning outcome," IFAC Proceedings Volumes, vol. 47, pp. 12232-12236, 2014.

[7] C. Creghan and K. Adair-Creghan, "The positive impact of project-based learning on attendance of an economically disadvantaged student population: A multiyear study," Interdisciplinary Journal of Problem-Based Learning, vol. 9, p. 7, 2015.

[8] D. N. Sari, S. Sutikno, and M. Masturi, "Pengaruh Pembelajaran Berbasis Proyek Terhadap Kreativitas Siswa Melalui Elektroskop Sederhana," in Prosiding Seminar Nasional Fisika (E-Journal), 2015, pp. SNF2015-I-19-24.

[9] R. Astuti, "Meningkatkan Kreativitas Siswa Dalam Pengolahan Limbah Menjadi Trash Fashion Melalui PjBL," Bioedukasi: Jurnal Pendidikan Biologi, vol. 8, pp. 37-41, 2015.

[10] S. Bell, "Project-based learning for the 21st century: Skills for the future," The Clearing House, vol. 83, pp. 39-43, 2010.

[11] U. Munandar, Pengembangan kreativitas anak berbakat: Departemen Pendidikan \& Kebudayaan, 1999.

[12] S. B. Djamarah and A. Zain, "Strategi belajar mengajar," ed: Jakarta: Rineka Cipta, 2006.

[13] S. P. Trianto and M. Pd, "Model-model Pembelajaran Inovatif Berorientasi Konstruktivistik," Jakarta: Prestasi Pustaka, 2007. 